\title{
Temporal shifts in seabird populations and spatial coherence with prey in the southeastern Bering Sea
}

\author{
Robert M. Suryan ${ }^{1, *}$, Kathy J. Kuletz ${ }^{2}$, Sandra L. Parker-Stetter ${ }^{3,7}$, Patrick H. Ressler ${ }^{4}$, \\ Martin Renner ${ }^{5}$, John K. Horne ${ }^{3}$, Edward V. Farley ${ }^{6}$, Elizabeth A. Labunski ${ }^{2}$ \\ ${ }^{1}$ Department of Fisheries and Wildlife, Oregon State University, Hatfield Marine Science Center, Newport, OR 97365, USA \\ ${ }^{2}$ US Fish and Wildlife Service, 1011 E Tudor Road, Anchorage, AK 99503, USA \\ ${ }^{3}$ School of Aquatic and Fishery Sciences, University of Washington, Box 355020, Seattle, WA 98195-5020, USA \\ ${ }^{4}$ Resource Assessment and Conservation Engineering Division, Alaska Fisheries Science Center, \\ National Marine Fisheries Service, National Oceanic and Atmospheric Administration, 7600 Sand Point Way NE, Seattle, \\ WA 98115, USA \\ ${ }^{5}$ Tern Again Consulting, 308 E Bayview Avenue, Homer, AK 99603, USA \\ ${ }^{6}$ Ted Stevens Marine Research Institute, Alaska Fisheries Science Center, National Marine Fisheries Service, \\ National Oceanic and Atmospheric Administration, 17109 Pt. Lena Loop Road, Juneau, AK 99801, USA \\ ${ }^{7}$ Present address: Fishery Resources Analysis and Monitoring Division, Northwest Fisheries Science Center, \\ National Marine Fisheries Service, National Oceanic and Atmospheric Administration, 2725 Montlake Boulevard East, Seattle, \\ WA 98112, USA
}

\begin{abstract}
The Bering Sea is a highly productive ecosystem with abundant prey populations in the summer that support some of the largest seabird colonies in the Northern Hemisphere. In the fall, the Bering Sea is used by large numbers of migrants and post-breeding seabirds. We used over $22000 \mathrm{~km}$ of vessel-based surveys carried out during summer (June to July) and fall (late August to October) from 2008 to 2010 over the southeast Bering Sea to examine annual and seasonal changes in seabird communities and spatial relationships with concurrently sampled prey. Deep-diving murres Uria spp., shallow-diving shearwaters Ardenna spp., and surface-foraging northern fulmars Fulmarus glacialis and kittiwakes Rissa spp. dominated summer and fall seabird communities. Seabird densities in summer were generally less than half of fall densities and species richness was lower in summer than in fall. Summer seabird densities had high interannual variation (highest in 2009), whereas fall densities varied little among years. Seabirds were more spatially clustered around breeding colonies and the outer continental shelf in the summer and then dispersed throughout the middle and inner shelf in fall. In summer, the abundance of age-1 walleye pollock Gadus chalcogrammus along with spatial (latitude and longitude) and temporal (year) variables best explained broad-scale seabird distribution. In contrast, seabirds in fall had weaker associations with spatial and temporal variables and stronger associations with different prey species or groups. Our results demonstrate seasonal shifts in the distribution and foraging patterns of seabirds in the southeastern Bering Sea with a greater dependence on prey occurring over the middle and inner shelf in fall.
\end{abstract}

KEY WORDS: Seabird · Forage fish · Krill · Spatial models · Seasonal patterns

\section{INTRODUCTION}

High latitude marine ecosystems undergo pronounced seasonal cycles that affect predator and prey populations. This is particularly true in the

\footnotetext{
${ }^{*}$ Corresponding author: rob.suryan@oregonstate.edu
}

Bering Sea, where seasonal variability in sea ice cover and annual variability in sea ice extent influence primary production and energy transfer to benthic and pelagic predator communities, including seabirds (Hunt et al. 2002b, 2011, Coyle et al. 2011, 
Stabeno et al. 2012b). In addition to seasonal variability, spatial variability affects mixing regimes and frontal boundaries that also impact seabird-prey assemblages (Jahncke et al. 2008, Hunt et al. 2014). Few high latitude seabird-prey studies, however, have been carried out outside of the summer breeding period, when species assemblages, individual activity budgets, and mortality patterns change markedly (Mason et al. 2007, Parrish et al. 2007, Renner et al. 2008, Santora 2014).

Predator response to temporal and spatial environmental variability is also affected by constraints imposed by species' life histories. For example, crossshelf variability in the Bering Sea favors diving seabirds that capture subsurface prey in shallow, inner shelf waters. In contrast, surface-feeding seabirds tend to be more abundant in the deeper waters of the outer shelf and shelf slope (Schneider \& Hunt 1982, Schneider et al. 1986, Hunt et al. 2014). During summer, many seabirds are central-place foragers, tied to a breeding colony while incubating eggs or feeding chicks. Central-place foraging constraints during the summer breeding period restrict foraging to varying radii around colonies to meet the energy demands of nestling growth and self-maintenance (Burke \& Montevecchi 2009, Paredes et al. 2012, Harding et al. 2013). During fall, seabirds are not constrained to forage from a central place or a nest-bound chick and, therefore, might change diets and spatial habitat affinities compared to those in summer. Post-breeding birds also must replenish energy reserves lost during the breeding season and regrow feathers during their annual molt. Feather molt, in particular, can cause some diving species, like murres, to become flightless, which limits travel distances in the search for food (Davoren et al. 2002, Markones et al. 2010). Adults of semi-precocial alcid species may also be limited in their movement while tending to a flightless chick (Markones et al. 2010). These and other factors highlight the need to better understand differences in seabird-prey-habitat associations between breeding and non-breeding periods.

We studied seasonal and interannual variability of seabirds and their association with key prey during summer and fall over $3 \mathrm{yr}$, from 2008 to 2010, in the southeastern Bering Sea (SEBS). We compared seabird species composition, distribution, and density during summer vs. fall and modeled seabird-prey relationships using concurrent vessel-based seabird and prey surveys. Our study was part of the Bering Study and the Bering Sea Integrated Ecosystem Research Project (hereafter 'Bering Sea Project') that sought to understand mechanisms of physical forcing and climate effects on food availability, trophic relationships, and spatio-temporal variability in predatorprey dynamics in the Bering Sea (Harvey \& Sigler 2013). The Bering Sea Project, along with prior ecosystem and long-term ecological studies, demonstrated that juvenile (age-0 to 1) walleye pollock Gadus chalcogrammus and euphaussiids (krill) were key prey items for seabirds in the SEBS in recent decades; however, capelin Mallotus villosus, sand lance Ammodytes hexapterus, and other prey also were regionally or historically important (Springer et al. 1986, Sinclair et al. 2008, Renner et al. 2012, Harding et al. 2013). Many seabird species in the Bering Sea are omnivorous, consuming different species of zooplankton and fishes, spatially between colonies or ecoregions, seasonally, and when self-feeding vs. provisioning chicks (Hunt et al. 2002a, Paredes et al. 2012, Renner et al. 2012, Harding et al. 2013). Abundance of these prey species can vary greatly by season, year, and region (Brodeur et al. 1999, 2002, Hollowed et al. 2012, Parker-Stetter et al. 2013, Ressler et al. 2014); for example, physical forcing from wind and winter sea ice extent over the shelf can greatly affect the distribution and abundance of fish populations in the SEBS (Hunt et al. 2002b, Stabeno et al. 2012a). Furthermore, changes in prey resources can have differential impacts on surface-feeding vs. diving piscivorous and planktivorous seabirds (Kitaysky \& Golubova 2000, Piatt et al. 2007).

In our examination of the spatial coherence of seabirds and their prey over 3 yr during summer and fall in the SEBS, we hypothesized that seabird spatial patterns and prey associations would vary among taxa, foraging guilds, behavioral groups (e.g. centralvs. non-central-place foraging), and season as water column stratification developed during summer breaks down during fall (Hunt et al. 2014). Furthermore, we hypothesized that prey abundance and water column structure would most strongly influence seabird density.

\section{MATERIALS AND METHODS}

\section{Study area and sampling design}

Our study area encompassed $400000 \mathrm{~km}^{2}$ on the SEBS continental shelf (Fig. 1). Major seabird colonies in or near the study area include St. Matthew Island in the north with 2.4 million birds, the Pribilof Islands on the outer shelf with 2.2 million birds, colonies on the inner shelf to the east with 250000 birds collectively, and near the Alaska peninsula and 
Fig. 1. Transect segments of vesselbased marine bird and acoustic prey surveys in the southeastern Bering Sea study area (black polygon), 2008 to 2010. Surveys were conducted during summer (02 June to 31 July) and fall (18 August to 05 October). Depth contours depict important bathymetric domains. White circles mark clusters of seabird colonies within or adjacent to the study area with $\geq 2$ million birds (large circles) or 10000 to 500000 birds (small circles).

Map: Alber's equal area projection

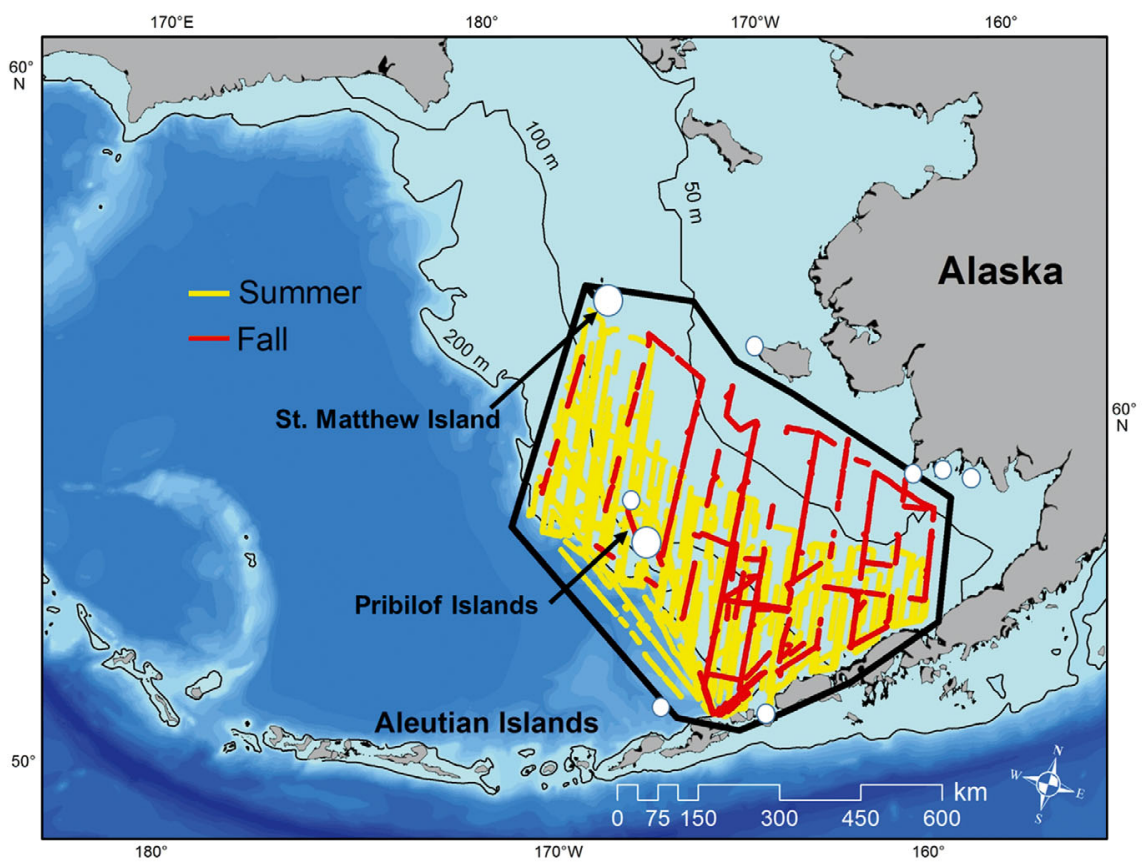

Aleutian Islands to the south with 500000 birds collectively (www.fws.gov/alaska/mbsp/mbm/north pacificseabirds/colonies/).

Seabird and acoustic-trawl prey transect surveys were conducted concurrently aboard NOAA vessels during the summer (02 June to 31 July) and fall (18 August to 05 October) from 2008 to 2010. We collected seabird data on ships of opportunity using the same methodologies during all seasons and years, allowing a comparison of seabird species composition, density, and distribution between summer and fall and among years. Prey data, however, were collected for different purposes in summer vs. fall and targeted different prey species and age classes each season. Summer acoustic-trawl surveys were conducted by NOAA's Midwater Assessment and Conservation Engineering (MACE) program to inform stock assessments of walleye pollock. The MACE surveys quantified water column density of age-1 and adult walleye Pollock, and euphausiids Thysanoessa raschii and T. inermis (De Robertis et al. 2010, Ressler et al. 2012, 2014). Fall acoustic-trawl surveys were conducted by NOAA's Bering-Aleutian Salmon International Survey (BASIS). Similar to the MACE surveys, BASIS quantified forage fish abundance in both the upper water column (above the pycnocline) and the whole water column; however BASIS targeted the epipelagic ecosystem to better understand salmon ecology (Farley et al. 2009, Parker-Stetter et al. 2013). (Table 1). Therefore, prey abundance could not be compared between seasons, but could be compared among years within seasons. Total survey effort varied among years and seasons (see Table S1 in the Supplement at www.int-res.com/articles/suppl/ m549p199_supp.pdf). Transects surveyed within a season among years or between seasons, however, did not always overlap, largely because summer surveys used randomized starting locations (Fig. 1). Therefore, we aggregated seabird and prey data within $37 \times 37 \mathrm{~km}$ grid cells (Sigler et al. 2012) throughout the study area for each season and year. When comparing seabird metrics between seasons within a year, we used only grid cells that were sampled during both seasons, so that seabird distribution and density were comparable. Hence, the number of grid cells used for seabird-prey analyses varied between seasons and among years. For comparisons of bird distribution and abundance between seasons, however, we use only those cells sampled in both seasons within a year (26 cells in 2008, 51 in 2009, and 56 in 2010; Table S1).

\section{Seabird data}

Seabird observers conducted over $22500 \mathrm{~km}$ of strip transect surveys (Tasker et al. 1984, USFWS 2009). Surveys were conducted during daylight hours from the same vessels used for acoustic-trawl prey surveys. An observer on the bridge of the vessel identified species, abundance, and behavior of seabirds within a $300 \mathrm{~m}$ strip transect width, sampled as a $90^{\circ}$ 
Table 1. Species, taxonomic groups, foraging guilds, and behavioral groups of seabirds and their prey used for seasonal (seabirds) and inter-annual (seabirds and prey) comparisons of distribution, abundance, and predator-prey associations in the southeastern Bering Sea, 2008 to 2010. Seasonal and annual comparisons and seabird-prey relationships were evaluated within, not among species or groups. Therefore, a given species may be represented in more than one taxonomic, foraging, or behavioral group. Northern fulmar were presented individually because they were numerically dominant in the study region and generally not confused with other species; taxonomic groups were used for similar seabird species that were sometimes difficult to distinguish at sea during strip transect surveys. Seabird foraging guilds represent the 4 main feeding modes, and behavioral groups represent different spatial patterns relative to colony locations. Fish and invertebrates representing main seabird prey were analyzed as individual species in summer, and as species and groups in fall

\begin{tabular}{|c|c|}
\hline Group & Species \\
\hline \multicolumn{2}{|c|}{ SEABIRDS - SUMMER AND FALL } \\
\hline \multicolumn{2}{|c|}{ Single species } \\
\hline Northern fulmar & Fulmarus glacialis \\
\hline \multicolumn{2}{|l|}{ Taxonomic group } \\
\hline Shearwaters & Short-tailed shearwater [primarily] Ardenna tenuirostris, sooty shearwater A. grisea \\
\hline Kittiwakes & Black-legged kittiwake [primarily] Rissa tridactyla, red-legged kittiwake $R$. brevirostris \\
\hline Gulls & $\begin{array}{l}\text { Glaucous-winged gull Larus glaucescens, glaucous gull L. hyperboreus, herring gull } \\
\text { L. argentatus, other Larus spp. }\end{array}$ \\
\hline Murres & Thick-billed murre [primarily] Uria lomvia, common murre U. aalge \\
\hline \multicolumn{2}{|l|}{ Foraging guilds } \\
\hline Diving piscivores & $\begin{array}{l}\text { All cormorants Phalacrocorax spp., murres, guillemots Cepphus spp., murrelets } \\
\text { Brachyramphus spp., rhinoceros auklet Cerorhinca monocerata, puffins Fratercula spp. }\end{array}$ \\
\hline Surface piscivores & Gulls, kittiwakes, terns Sterna spp. \\
\hline Diving planktivores & Auklets (Ptychoramphus aleuticus, and Aethia spp.) \\
\hline Surface planktivores & Phalaropes Phalaropus spp., storm-petrels Oceanodroma spp. \\
\hline \multicolumn{2}{|l|}{ Behavioral groups } \\
\hline Central-place foragers & $\begin{array}{l}\text { Northern fulmar, storm-petrels, cormorants, gulls, kittiwakes, terns, murres, guillemots, } \\
\text { murrelets, auklets, puffins }\end{array}$ \\
\hline Non-central-place foragers & Albatrosses Phoebastria spp., shearwaters, phalaropes, jaegers Stercorarius spp. \\
\hline \multicolumn{2}{|l|}{ PREY - SUMMER } \\
\hline \multicolumn{2}{|l|}{ Single species } \\
\hline Euphausiids & Thysanoessa spp. \\
\hline Age-1 walleye pollock & Gadus chalcogrammus \\
\hline \multicolumn{2}{|l|}{ PREY-FALL } \\
\hline \multicolumn{2}{|l|}{ Single species } \\
\hline Capelin & Mallotus villosus \\
\hline Age-0 Pacific cod & G. macrocephalus \\
\hline Age-0 walleye pollock & \\
\hline \multicolumn{2}{|l|}{ Forage group } \\
\hline Forage fish & Capelin, age-0 Pacific cod, age-0 walleye pollock \\
\hline Other & $\begin{array}{l}\text { Pacific herring Clupea pallasii, age-1+ walleye pollock, age-1+ Pacific cod, Pacific sand } \\
\text { lance Ammodytes hexapterus, stickleback (Gasterosteus aculeatus, Pungitius pungitius), } \\
\text { juvenile rockfish Sebastes spp, Bering wolffish Anarhichas orientalis, Pacific sandfish } \\
\text { Trichodon trichodon, rainbow smelt Osmerus mordax, prowfish Zaprora silenus, and } \\
\text { juvenile Atka mackerel Pleurogrammus monopterygius }\end{array}$ \\
\hline
\end{tabular}

arc from the bow to the beam and out to $300 \mathrm{~m}$ from the vessel while in transit. Observers surveyed on either side of the vessel, depending on observing conditions. In our analysis, we included surveys conducted during a Beaufort sea state $\leq 6$, as sightings decreased significantly with sea states $\geq 7$ (Sigler et al. 2012). When viewing conditions were restricted, the survey strip width was reduced to 100 or $200 \mathrm{~m}$. Continuous transect lines were divided into $3 \mathrm{~km}$ segments to calculate the density (ind. $\mathrm{km}^{-2}$ ) of all seabirds sighted, whether on water or in air. We then calculated seasonal and annual seabird density for each $37 \times 37 \mathrm{~km}$ grid cell by averaging all $3 \mathrm{~km}$ segments within each cell. Survey effort per season ranged from 954 to $6032 \mathrm{~km}$, with a mean of 8 to 13 survey segments per cell (Table S1).

Given that foraging behavior, diet, and breeding status can all affect seabird distribution and seabirdprey relationships (Davoren et al. 2002, Benoit-Bird et al. 2011, Sigler et al. 2012, Jones et al. 2014), we analyzed seabird density data at several taxonomic, foraging niche, and behavioral levels. Northern fulmar Fulmarus glacialis were examined individually because they were abundant and widespread in both 
summer and fall. Four taxonomic groups were examined because their genera were abundant and widespread but species were sometimes difficult to distinguish, leading to high proportions of 'unidentified' within the genera; these included shearwaters (primarily sooty, Ardenna grisea), kittiwakes (primarily black-legged, Rissa tridactyla), murres (primarily thick-billed, Uria lomvia), and gulls (see Table 1 for a complete list of species included). Four foraging groups were analyzed, based on diving or surfacefeeding, and primary diet being planktivorous or piscivorous (Table 1). Finally, we analyzed all species and taxonomic groups, including less abundant species, as to whether they were central-place foragers or seasonal migrants (non-central-place foragers). Central-place foraging seabirds are those that breed in the study area and forage from a central colony during summer months (June and July in our study). Central-place foraging species become non-central-place foragers during fall (mid-August to early October in our study). Species that breed during winter and spring outside of our study area occurred within our study area (e.g. shearwaters Ardenna spp. and albatrosses Phoebastria spp.) as non-breeding and noncentral-place foragers during both seasons and allowed for comparisons of distribution between summer and fall that were not affected by colony attendance. Unidentified species were included in the lowest taxonomic or foraging category possible or excluded from analyses.

\section{Summer prey data}

Herein, we provide an overview of methods for estimating the biomass density of prey ( $\mathrm{kg}$ nautical mile $[\mathrm{nmi}]^{-2}$ ) during summer (2 June to 31 July) acoustic surveys conducted from the NOAA Ship 'Oscar Dyson'; see Honkalehto et al. (2010) and Ressler et al. (2012) for detailed methodologies. Briefly, we measured the abundance of age-1 pollock and euphausiids using acoustic backscatter data paired with midwater and bottom trawling along north-south transects spaced $37 \mathrm{~km}$ apart during daylight hours within the study area (Fig. 1).

Acoustic backscatter was measured with a Simrad EK60 split-beam echosounder $(18,38,70,120$, and

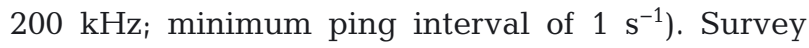
speeds were 19 to $22 \mathrm{~km} \mathrm{~h}^{-1}$. The effective sampling depth of transducers mounted on the hull of the ship began 15 to $20 \mathrm{~m}$ below the water surface (due to a combination of transducer depth and avoiding low frequency near-field effects near transducers). We assumed that prey available to surface-feeding seabirds was similar to prey measured at 15 to $20 \mathrm{~m}$ depth. We attributed acoustic backscatter at $38 \mathrm{kHz}$ to walleye pollock biomass at length based on visual examination of the acoustic signal, targeted midwater and bottom trawls to identify species composition of the acoustic signal, and empirical target strengthlength (Traynor 1996) and length-weight relationships. The length-at-age thresholds for age-1 pollock were individuals greater than $9 \mathrm{~cm}$ and less than 17 , 19, and $20 \mathrm{~cm}$ for 2008, 2009 and 2010, respectively. Acoustic backscatter at $120 \mathrm{kHz}$ was attributed to euphausiids using multi-frequency methods and converted to biomass using an empirical algorithm based on backscatter frequency response and targeted midwater trawling (De Robertis et al. 2010, Ressler et al. 2012).

\section{Fall prey data}

Here we provide an overview of fall (18 August to 5 October) prey sampling methods; see ParkerStetter et al. (2013) and Farley et al. (2009) for detailed methodologies of acoustic and trawl surveys, respectively. We collected acoustic data continuously in transit between stations where surface trawl sampling occurred (Fig. 1). Surface trawls (all years) were conducted every $65 \mathrm{~km}$ north-south and midwater trawls (2009 to 2010) were typically conducted once per day for acoustic target identification. The number of transects and spatial extent of sampling (Table S1) increased from 2008 to 2010. Additionally, stations were sampled at different spatial resolutions among years. In 2008 and 2009, stations were spaced $120 \mathrm{~km}$ east-west by $65 \mathrm{~km}$ northsouth. In 2010, stations were spaced $65 \mathrm{~km}$ apart in both directions. The surveys were conducted during daylight hours. The water column was sampled via active acoustics from 15 to $400 \mathrm{~m}$ depth, except during 2008 when the maximum bottom depth sampled was $100 \mathrm{~m}$. Similar to summer surveys, the upper $15 \mathrm{~m}$ of the water column was not sampled acoustically due to the depth of the transducers mounted on the hull of the vessel. However, fish samples within the top $25 \mathrm{~m}$ of the water column were collected with the surface trawl at the resolution mentioned above (see Farley et al. 2009).

We collected fall acoustic data in 2 different ways. We used hull-mounted Simrad ES60 echosounders (38 kHz) aboard charted fishing vessels or Simrad EK60 split-beam echosounder $(18,38,70,120$, and $200 \mathrm{kHz}$ ) aboard the NOAA Ship 'Oscar Dyson'. To 
standardize comparisons across all vessels, we used only the $38 \mathrm{kHz}$ data. We calculated backscatter (nautical area scattering coefficient [NASC], $\mathrm{m}^{2}$ $\mathrm{nmi}^{-2}$ ) for 2 depth zones, surface and water column, depending on whether or not the water column was stratified. Surface zone estimates were derived from acoustic backscatter of fish above the pycnocline (an acoustically detected layer related to the oceanographic mixed layer depth, i.e. depth of the top of the pycnocline; Parker-Stetter et al. 2013). Water column estimates were calculated for both stratified and mixed water columns. For mixed water columns in shallow water $(<35 \mathrm{~m}$ depth), surface and water column estimates were the same and used interchangeably.

Acoustic backscatter was partitioned to species using target strength estimates based on the fish's measured length and specific species, similar species, or generalized length vs. target strength equations from the literature (see Table S1 in ParkerStetter et al. 2013). We calculated species-specific backscatter for capelin, age-0 Pacific cod Gadus macrocephalus, and age-0 walleye pollock, a combined category of these 3 species (referred to as 'forage fish'), and a separate category for the remaining species ('other fish') (Table 1).

\section{Analysis}

We used ANOVA, or a non-parametric equivalent when parametric assumptions were violated, to compare means between seasons and among years with season-year interactions. We used Moran's index of dispersion (Moran's I, value range -1 to 1 ) to calculate spatial autocorrelation and test if the distribution of seabirds or prey was clustered, random or dispersed and whether the pattern changed between seasons (seabirds) or among years (seabirds and prey). A significant Moran's I indicates that the spatial pattern among grid cells is significantly different from a random distribution. Significant positive values of Moran's I indicate clustering whereas negative values indicate dispersion. We used a distance band of $85 \mathrm{~km}$ in the Moran's I calculation, so that at least 2 grid cells in any direction from the cell being evaluated would be included (up to 16 cells, but generally $~ 8$ cells due to an imperfectly sampled grid in some seasons or years) and specified inverse Euclidean distance for calculating spatial relationships.

We used generalized additive models (GAM) and the 'mgcv' package v1.7-22 (Wood 2004, 2006) in the computer program R v3.0.1 (R Core Team 2013) to model seabird density as a function of prey density, bottom water temperature, and spatial variables of seafloor depth, latitude, and longitude. Seabird density response variables and prey density predictor variables were $\log _{10}$ transformed prior to analysis. Predictor variables other than year were modeled with nonlinear smoothing terms. Year was modeled as a factor. The full summer model had the following form:

$$
\begin{gathered}
\text { seabirds } \sim \mathrm{s}(\text { pol1 })+\mathrm{s}(\text { euph })+\mathrm{s}(\text { bot_depth })+ \\
\mathrm{s}(\text { bot_temp })+\mathrm{s}(\text { lat })+\mathrm{s}(\text { lon })+\mathrm{yr}+e
\end{gathered}
$$

where pol1 = age-1 walleye pollock biomass density, euph = euphausiid biomass density, bot_depth = average bottom depth of grid cell, bot_temp = average bottom temperature of grid cell, lat = latitude, lon = longitude, and yr = year.

Full fall models took 3 primary forms that varied by the categories of prey densities included:

$$
\begin{aligned}
& \text { seabirds } \sim \text { s(all_prey) + s(bot_depth })+ \text { s(bot_temp })+ \\
& \mathrm{s}(\text { layer_bot })+\mathrm{s}(\mathrm{lat})+\mathrm{s}(\mathrm{lon})+\mathrm{yr}+\mathrm{e} \\
& \text { seabirds } \sim \text { s(fofi) }+ \text { s(bot_depth })+s(\text { bot_temp })+ \\
& \mathrm{s}(\text { layer_bot })+\mathrm{s}(\text { lat })+\mathrm{s}(\text { lon })+\mathrm{yr}+e \\
& \text { seabirds } \sim \mathrm{s}(\text { cape })+\mathrm{s}(\text { pcod } 0)+\mathrm{s}(\text { pol0 })+\mathrm{s}(\text { othsp })+ \\
& \text { s(bot_depth })+s(\text { bot_temp })+\text { s(layer_bot })+s(\text { lat })+ \\
& \mathrm{s}(\mathrm{lon})+\mathrm{yr}+e
\end{aligned}
$$

where prey densities in these models included NASC of the following: all_prey = all prey categories combined, fofi $=$ key forage species (Table 1 ), cape $=$ capelin, pcodo $=$ age -0 Pacific $\operatorname{cod}$, pol0 = age-0 walleye pollock, and othsp = other fish species; and spatio-temporal variables were layer_bot $=$ pycnocline depth, and the remaining variables to same as for summer. Prey categories that were compilations or subsets of one another were analyzed in separate models. Water depth and bottom water temperature in fall were not available for all grid cells and were not important explanatory variables; they were therefore excluded from final analyses to maximize sample sizes. The 3 fall models also were run separately for water column prey density estimates and near-surface (above pycnocline) prey densities with results reported separately. All model families were Gaussian with identity link functions. We used Akaike's information criteria (AIC) to test whether retaining all variables in full models resulted in overfitting relative to removing insignificant $(p>0.05)$ variables and to select among the 3 full models used in fall analyses. 


\section{RESULTS}

\section{Seabird abundance and distribution}

Overall seabird species richness was lower in the summer (42 species) vs. fall (54 species) (Fig. 2). Species not observed in the summer that were present in the fall included eiders Somateria spp. and shorebirds; moreover, in the fall, a greater variety of loons Gavia spp., gulls, and grebes were observed. Density of total seabirds, the numerically dominant taxa, and all foraging guilds except surface planktivores was generally lower in summer vs. fall (Table 2). Instances where summer seabird density was greater or not significantly different in summer vs. fall were identified by a season $x$ year interaction $(p<0.002)$ and included surface planktivores, centralplace foragers, and northern fulmars, in addition to total seabirds, all in 2009. For these groups in 2008 and 2010, summer densities were generally less than half of fall densities, whereas in 2009 densities showed considerably less seasonal variation or even greater abundance in summer vs. fall for some taxonomic groups (e.g. surface planktivores and northern fulmars; Table 2).

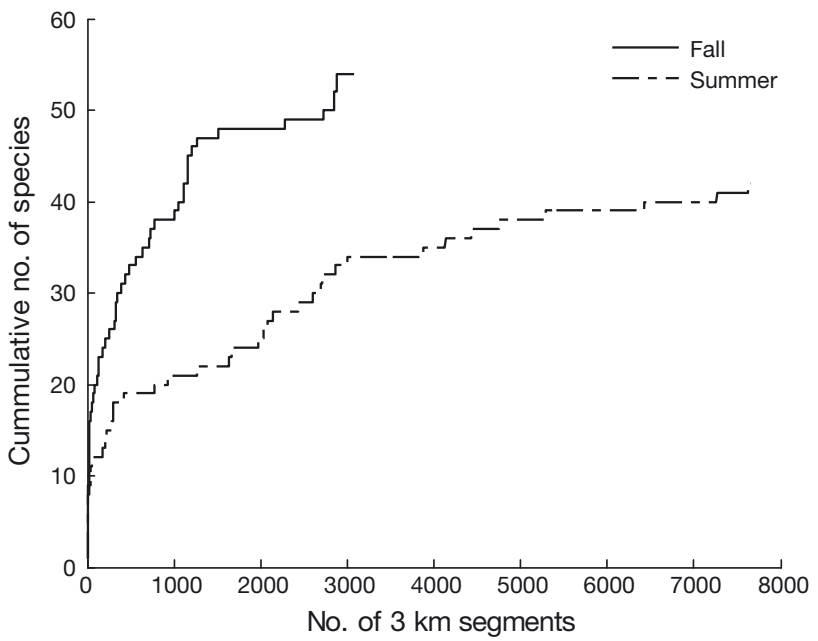

Fig. 2. Avian species richness in summer vs. fall at-sea surveys in the southeast Bering Sea, 2008 to 2010. Richness is the cumulative number of species for each $3 \mathrm{~km}$ segment of strip transect

Seabirds, in general, were more clustered at sea during summer compared to fall. Although Moran's I for seabirds (except for non-central-place foragers in summer 2010) showed a non-random, clustered distribution for both summer and fall (i.e. $Z>0, p<0.05$ ),

Table 2. Comparison of $\log$-transformed $\left(\log _{10}[x+1]\right)$ seabird density (ind. $\left.\mathrm{km}^{-2}\right)$ in the southeastern Bering Sea between seasons and among years (2008 to 2010) according to species and groups defined in Table 1. Values shown are means with ranges in parentheses. Sample sizes are the number of $37 \times 37 \mathrm{~km}$ grid cells sampled each year during both summer and spring: $\mathrm{n}=26$ cells in 2008, 51 in 2009, and 56 in 2010. Non-significant ANOVA results ( $\mathrm{p}>0.05$ ) are marked as 'ns'. Statistical comparisons were conducted within, not between, species or groups

\begin{tabular}{|c|c|c|c|c|c|c|c|c|c|}
\hline \multirow{2}{*}{ Species or group } & \multicolumn{2}{|c|}{$-2008-$} & \multicolumn{2}{|c|}{$2009-$} & \multicolumn{2}{|c|}{$2010-$} & \multirow[b]{2}{*}{ Season } & \multirow{2}{*}{$\begin{array}{l}\mathrm{p}- \\
\text { Year }\end{array}$} & \multirow[b]{2}{*}{ Season*Year } \\
\hline & Summer & Fall & Summer & Fall & Summer & Fall & & & \\
\hline Total seabirds & $\begin{array}{c}0.34 \\
(0-0.91)\end{array}$ & $\begin{array}{c}0.93 \\
(0.33-1.46)\end{array}$ & $\begin{array}{c}0.86 \\
(0.03-2.02)\end{array}$ & $\begin{array}{c}1.03 \\
(0-1.64)\end{array}$ & $\begin{array}{c}0.48 \\
(0-1.43)\end{array}$ & $\begin{array}{c}0.93 \\
(0.34-1.85)\end{array}$ & $<0.001$ & $<0.00$ & 0.001 \\
\hline Diving piscivores & $\begin{array}{c}0.14 \\
(0-0.47)\end{array}$ & $\begin{array}{c}0.38 \\
(0-1.12)\end{array}$ & $\begin{array}{c}0.29 \\
(0-1.01)\end{array}$ & $\begin{array}{c}0.47 \\
(0-1.09)\end{array}$ & $\begin{array}{c}0.23 \\
(0-1.13)\end{array}$ & $\begin{array}{c}0.4 \\
(0-1.05)\end{array}$ & $<0.001$ & 0.027 & ns \\
\hline Diving planktivores & $\begin{array}{c}0.02 \\
(0-0.08)\end{array}$ & $\begin{array}{c}0.05 \\
(0-0.27)\end{array}$ & $\begin{array}{c}0.02 \\
(0-0.22)\end{array}$ & $\begin{array}{c}0.09 \\
(0-0.42)\end{array}$ & $\begin{array}{c}0.03 \\
(0-0.73)\end{array}$ & $\begin{array}{c}0.13 \\
(0-0.73)\end{array}$ & $<0.001$ & ns & ns \\
\hline Surface piscivores & $\begin{array}{c}0.02 \\
(0-0.14)\end{array}$ & $\begin{array}{c}0.22 \\
(0-0.82)\end{array}$ & $\begin{array}{c}0.1 \\
(0-0.69)\end{array}$ & $\begin{array}{c}0.26 \\
(0-0.87)\end{array}$ & $\begin{array}{c}0.02 \\
(0-0.29)\end{array}$ & $\begin{array}{c}0.2 \\
(0-0.65)\end{array}$ & $<0.001$ & 0.001 & ns \\
\hline Surface planktivores & $\begin{array}{c}0.01 \\
(0-0.17)\end{array}$ & $\begin{array}{c}0.06 \\
(0-0.26)\end{array}$ & $\begin{array}{c}0.22 \\
(0-1.88)\end{array}$ & $\begin{array}{c}0.12 \\
(0-0.73)\end{array}$ & $\begin{array}{c}0.06 \\
(0-0.53)\end{array}$ & $\begin{array}{c}0.18 \\
(0-1.26)\end{array}$ & ns & 0.001 & 0.001 \\
\hline $\begin{array}{l}\text { Central-place } \\
\text { foragers }\end{array}$ & $\begin{array}{c}0.3 \\
(0-0.91)\end{array}$ & $\begin{array}{c}0.81 \\
(0-1.29)\end{array}$ & $\begin{array}{c}0.76 \\
(0.03-2.01)\end{array}$ & $\begin{array}{c}0.91 \\
(0-1.47)\end{array}$ & $\begin{array}{c}0.45 \\
(0-1.41)\end{array}$ & $\begin{array}{c}0.85 \\
(0.16-1.54)\end{array}$ & $<0.001$ & $<0.00$ & 0.002 \\
\hline $\begin{array}{l}\text { Non-central-place } \\
\text { foragers }\end{array}$ & $\begin{array}{c}0.05 \\
(0-0.38)\end{array}$ & $\begin{array}{c}0.3 \\
(0-1.30)\end{array}$ & $\begin{array}{c}0.25 \\
(0-1.40)\end{array}$ & $\begin{array}{c}0.36 \\
(0-1.50)\end{array}$ & $\begin{array}{c}0.05 \\
(0-0.89)\end{array}$ & $\begin{array}{c}0.29 \\
(0-1.58)\end{array}$ & $<0.001$ & 0.005 & ns \\
\hline Northern fulmar & $\begin{array}{c}0.17 \\
(0-0.90)\end{array}$ & $\begin{array}{c}0.43 \\
(0-0.90)\end{array}$ & $\begin{array}{c}0.49 \\
(0.02-1.29)\end{array}$ & $\begin{array}{c}0.44 \\
(0-1.00)\end{array}$ & $\begin{array}{c}0.24 \\
(0-0.80)\end{array}$ & $\begin{array}{c}0.43 \\
(0-1.39)\end{array}$ & 0.001 & 0.001 & 0.002 \\
\hline Shearwaters & $\begin{array}{c}0.05 \\
(0-0.38)\end{array}$ & $\begin{array}{c}0.25 \\
(0-1.30)\end{array}$ & $\begin{array}{c}0.24 \\
(0-1.40)\end{array}$ & $\begin{array}{c}0.32 \\
(0-1.50)\end{array}$ & $\begin{array}{c}0.05 \\
(0-0.89)\end{array}$ & $\begin{array}{c}0.26 \\
(0-1.58)\end{array}$ & $<0.001$ & 0.006 & ns \\
\hline Kittiwakes & $\begin{array}{c}0.02 \\
(0-0.14)\end{array}$ & $\begin{array}{c}0.19 \\
(0-0.78)\end{array}$ & $\begin{array}{c}0.1 \\
(0-0.69)\end{array}$ & $\begin{array}{c}0.22 \\
(0-0.87)\end{array}$ & $\begin{array}{c}0.02 \\
(0-0.29)\end{array}$ & $\begin{array}{c}0.14 \\
(0-0.63)\end{array}$ & $<0.001$ & $<0.00$ & ns \\
\hline Murres & $\begin{array}{c}0.11 \\
(0-0.46)\end{array}$ & $\begin{array}{c}0.19 \\
(0-0.90)\end{array}$ & $\begin{array}{c}0.22 \\
(0-1.00)\end{array}$ & $\begin{array}{c}0.4 \\
(0-1.08)\end{array}$ & $\begin{array}{c}0.18 \\
(0-1.07)\end{array}$ & $\begin{array}{c}0.29 \\
(0-1.03)\end{array}$ & $<0.001$ & 0.001 & ns \\
\hline
\end{tabular}


the Moran's I values were considerably higher in summer vs. fall (more than double for central-place foragers), indicating a greater degree of spatial clustering during summer (Table 3). A shift in the centers of distribution from the western (outer) and southern margin of the continental shelf (where most of the breeding colonies are) to the inner continental shelf is evident in the mapped distribution of seabirds (Fig. 3, Figs. S1-S4 in the Supplement at www.int-res.com/ articles/suppl/m549p199_supp.pdf). The shift in distribution was not exclusively an effect of central-place breeding seabirds dispersing from colonies in the fall (Figs. S1-S3) because even migratory, non-breeding species such as shearwaters were more clustered in summer than in fall during 1 of 2 years in which comparisons could be made (Table 3, Fig. S4).

\section{Prey abundance and distribution}

Water column fish density (indexed by biomass density in summer, $\mathrm{kg} \mathrm{nmi}{ }^{-2}$, and acoustic backscatter NASC in fall, $\mathrm{m}^{2} \mathrm{nmi}^{-2}$ ) was half to 10 times lower in 2008 for both summer and fall (with the exception of age-0 Pacific cod and walleye pollock in fall) compared to 2009 and 2010 (Table 4). Forage fish density in the surface zone (generally above the pycnocline) during fall, however, showed an opposite trend, with high values in 2008 and 2010 and lowest values in 2009 (Table 4). Reduced forage fish density in 2009 was most evident in age-0 Pacific cod and age-0 walleye pollock, with an opposite trend for capelin, which showed an increase from 2008 to 2009. In contrast to highly variable forage fish densities, euphausiid biomass density in summer remained relatively consistent and did not significantly differ in mesoscale acoustic backscatter in all 3 years (range
5.72 to $5.79 \mathrm{~kg} \mathrm{nmi}^{-2} ; F=0.699, \mathrm{p}=0.498$; Table 4). Euphausiids also had a far less clustered distribution than forage fishes, with the exception of age-1 pollock in summer of 2008 (Table 3).

\section{Seabird and prey spatial models}

In summer, age-1 walleye pollock and spatial (latitude and longitude) variables were important components of competing models for all species or foraging guilds except diving planktivores and gulls (Table 5). The model that explained the greatest amount of variability $\left(\mathrm{R}^{2}=67 \%\right)$ was for centralplace-foragers, followed by all seabirds, surface planktivores, northern fulmars, murres, and diving piscivores whose models all had $>50 \%$ of deviance explained (range 51 to $68 \%$ ). Seabird prey and spatial habitat response curves for the 2 most abundant seabirds, northern fulmar and murres, showed contrasting response shapes. Both species had somewhat similar response relationships to the biomass density of age-1 pollock, but contrasting responses to latitude and longitude (Fig. 4). Northern fulmar density had a positive response with westerly longitudes, increasing toward the central and outer continental shelf, whereas murre density peaked at $170^{\circ} \mathrm{W}$ longitude (Fig. 4). Biomass of euphausiids was a significant predictor for non-central-place foragers, i.e. shearwaters (positive), and diving planktivores (negative). The best fit model $\left(\mathrm{R}^{2}=67 \%\right)$ was for central-place foraging seabird species and in addition to prey included spatial, and temporal variables (Table 5), indicating the importance of a colony effect of breeding seabirds during summer, cross-shelf patterns in distribution, and the significant interannual variability in seabird abundance.

Table 3. Moran's $I$ (with $Z$ scores in parentheses) of spatial autocorrelation for mean densities $\left(\log _{10}[x+1]\right)$ of seabirds and prey (see Table 1 for species) among grid cells in the southeastern Bering Sea, 2008 to 2010. Prey were acoustically sampled for the water column (wcol) summer and fall and in the near-surface layer (surf), i.e. above the pycnocline, in fall. All Moran's I values except non-central-place foragers in summer 2010 were positive and significantly different $(p<0.05)$ from a random distribution, indicating a clustered rather than random or dispersed distribution. na: It was not possible to calculate Moran's $I$ because too few and distantly spaced grid cells were sampled for comparison; ns: not significant

\begin{tabular}{|c|c|c|c|c|c|c|}
\hline \multirow{2}{*}{ Species or group } & \multicolumn{2}{|c|}{2008} & \multicolumn{2}{|c|}{-2009} & \multicolumn{2}{|c|}{2010} \\
\hline & Summer & Fall & Summer & Fall & Summer & Fall \\
\hline Total seabirds & na & na & $0.66(7.5)$ & $0.37(4.4)$ & $0.48(7.2)$ & $0.27(4.1)$ \\
\hline Central-place foragers & na & na & $0.62(7.1)$ & $0.23(2.9)$ & $0.60(8.9)$ & $0.25(3.9)$ \\
\hline Non-central-place foragers & na & na & $0.60(7.2)$ & $0.43(5.1)$ & $0.07\left(1.5^{\mathrm{ns}}\right)$ & $0.24(3.8)$ \\
\hline Age-1 pollock wcol & $0.13(7.7)$ & - & $0.56(19.8)$ & - & $0.60(21.7)$ & - \\
\hline Euphausiids wcol & $0.20(7.3)$ & - & $0.06(2.4)$ & - & $0.14(5.2)$ & - \\
\hline Forage fish wcol & - & $0.36(3.3)$ & - & $0.59(7.6)$ & - & $0.53(11.3)$ \\
\hline Forage fish surf & - & $0.48(4.1)$ & - & $0.38(5.0)$ & - & $0.46(10.0)$ \\
\hline
\end{tabular}



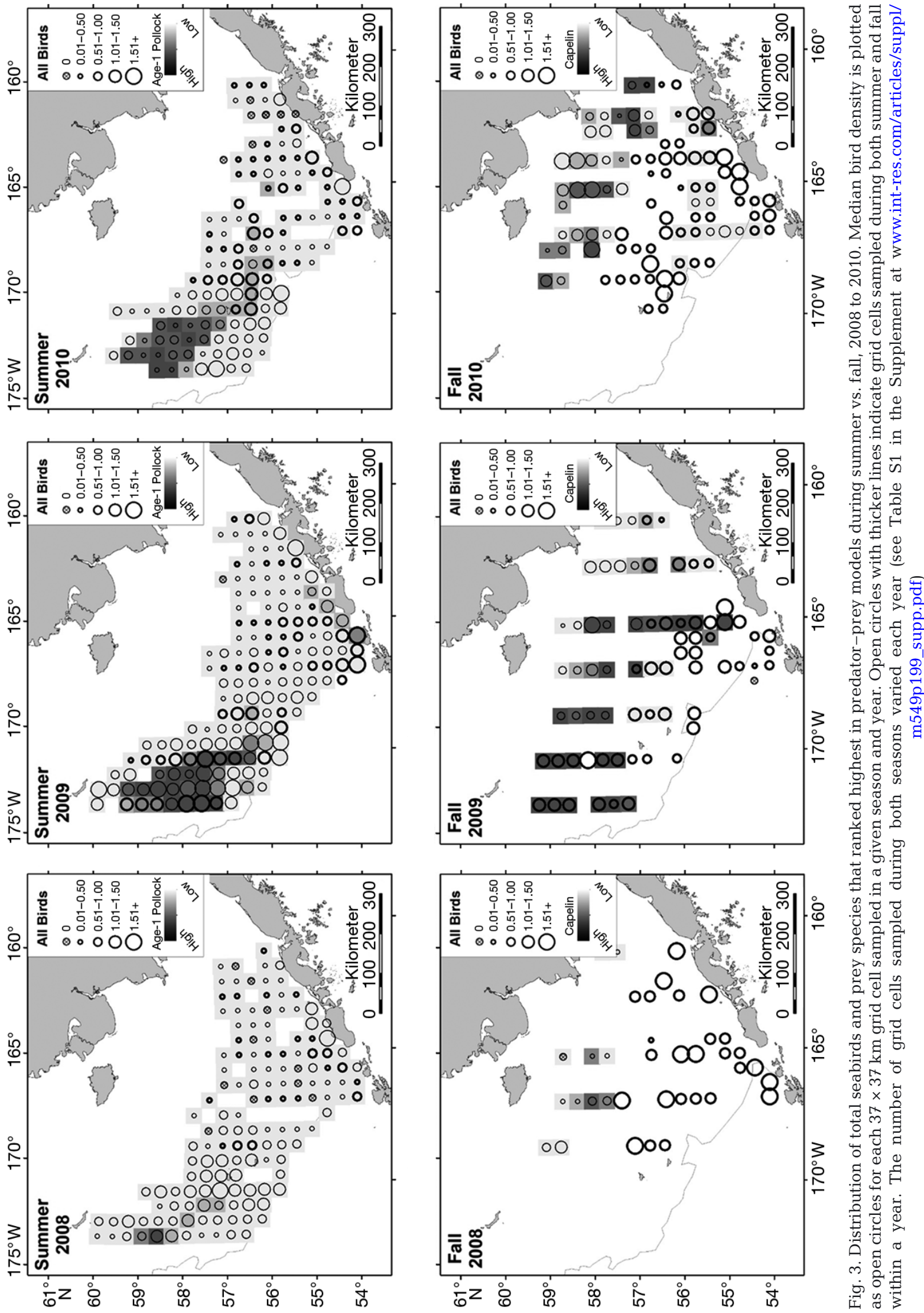
Table 4. Interannual variation of log-transformed $\left(\log _{10}[x+1]\right)$ mean $(n, S E)$ biomass density $\left(\mathrm{kg} \mathrm{nmi}^{-2}\right)$ of seabird prey species (see Table 1 for details) in summer, and acoustic backscatter (NASC, $\mathrm{m}^{2} \mathrm{nmi}^{-2}$ ) from fall hydroacoustic surveys in the southeastern Bering Sea survey area, 2008 to 2010. Test statistic shows result of a Kruskal-Wallace test $\left(X^{2}\right)$ or ANOVA $(F)$

\begin{tabular}{|c|c|c|c|c|c|}
\hline Species or group & 2008 & 2009 & 2010 & Test statistic & $\mathrm{p}$ \\
\hline \multicolumn{6}{|l|}{ Summer } \\
\hline \multicolumn{6}{|l|}{ Water column } \\
\hline Age-0 pollock & $0.05(171,0.02)$ & $0.48(170,0.09)$ & $0.37(172,0.07)$ & $X^{2}=18.0$ & $<0.001$ \\
\hline Euphausiids & $5.72(168,0.05)$ & $5.79(167,0.37)$ & $5.76(167,0.50)$ & $F=0.7$ & $\mathrm{~ns}$ \\
\hline \multicolumn{6}{|l|}{ Fall } \\
\hline \multicolumn{6}{|l|}{ Surface } \\
\hline All forage fishes & $1.37(41,0.13)$ & $0.53(69,0.07)$ & $1.11(92,0.08)$ & $X^{2}=38.9$ & $<0.001$ \\
\hline Capelin & $0.17(41,0.05)$ & $0.34(69,0.06)$ & $0.40(92,0.05)$ & $X^{2}=6.1$ & 0.047 \\
\hline Age-0 Pacific cod & $0.78(41,0.11)$ & $0.07(69,0.04)$ & $0.54(92,0.11)$ & $X^{2}=55.7$ & $<0.001$ \\
\hline Age- 0 pollock & $1.25(41,0.12)$ & $0.15(69,0.04)$ & $0.62(92,0.08)$ & $X^{2}=60.8$ & $<0.001$ \\
\hline \multicolumn{6}{|l|}{ Water column } \\
\hline All forage fishes & $0.68(15,0.06)$ & $1.24(69,0.09)$ & $1.40(64,0.90)$ & $X^{2}=8.1$ & 0.017 \\
\hline Capelin & $0.18(15,0.07)$ & $0.60(69,0.07)$ & $0.43(64,0.07)$ & $X^{2}=8.0$ & 0.018 \\
\hline Age-0 Pacific cod & $0.17(15,0.08)$ & $0.08(69,0.04)$ & $0.71(64,0.11)$ & $X^{2}=24.4$ & $<0.001$ \\
\hline Age-0 pollock & $0.58(15,0.13)$ & $0.97(69,0.09)$ & $0.94(64,0.14)$ & $X^{2}=2.4$ & ns \\
\hline
\end{tabular}

The more common occurrence of age- 1 walleye pollock biomass rather than euphausiid biomass in final models is consistent with the less patchy distribution of euphausiids and the dominance of piscivores in the avian community composition (Table 3). Euphausiid biomass did occur in models, along with age-1 walleye pollock, of central-place foragers and shearwaters.

In fall, seabirds had a more variable association with prey, spatial, and temporal variables compared to summer. Models including water column rather than surface (above the pycnocline) estimates of prey density generally had better fits, with the exception of diving and surface-feeding planktivores (Table 6). Northern fulmars and murres had the strongest relationships $\left(\mathrm{R}^{2}=0.66\right.$ and 0.44 , respectively) with prey and habitat, whereas gulls and surface planktivores had the weakest model fits $\left(\mathrm{R}^{2}=0.18\right.$ and 0.13 , respectively). Northern fulmar abundance was best explained by age-0 Pacific cod (peaked response

Table 5. Results of generalized additive models (GAM) of prey abundance and distribution that best explain variation in summer $\log _{10}(x+1)$-transformed seabird density in the southeastern Bering Sea, 2008 to $2010(\mathrm{n}=433 \mathrm{grid}$ cells, $37 \times 37 \mathrm{~km})$. See Table 1 for seabird species included in species groupings; annual sample sizes are provided in Table S1 in the Supplement. Prey abundance and spatial variables include age-1 pollock (Pol1), euphausiids (Euph), year, latitude, and longitude. All variables are quantitative, except year, which was modeled as a factor. GAM results include adjusted $\mathrm{R}^{2}$, percent deviance explained, $\triangle \mathrm{AIC}$, estimated degrees of freedom for significant smoothed variables, and their significance indicated as ${ }^{*} \mathrm{p}<$ 0.05 or ${ }^{* *} \mathrm{p}<0.001$. Superscript ${ }^{2}$ indicates a negative linear relationship. (-) indicates that the variable was included in the final model but was not significant. $\triangle$ AIC is the decrease in AIC between a model with all variables in the table retained vs. a model containing only the significant variables. All models below showed improved fit, i.e. negative $\Delta$ AIC, over a simple spatial model including only latitude and longitude

\begin{tabular}{|c|c|c|c|c|c|c|c|c|}
\hline Species or group & $\mathrm{R}^{2}$ & $\% \mathrm{dev}$ & $\Delta \mathrm{AIC}$ & Pol1 & Euph & Lat & Long & Year \\
\hline Central-place foragers & 0.67 & 68.5 & 74.2 & $7.20^{* *}$ & - & $4.67^{* *}$ & $7.90^{* *}$ & * \\
\hline All seabirds & 0.61 & 63.3 & 77.0 & $6.62^{* *}$ & - & $4.52^{* *}$ & $7.33^{* *}$ & * \\
\hline Surface planktivores & 0.58 & 59.7 & 34.6 & $7.92^{* *}$ & - & $4.48^{* *}$ & $3.41^{* *}$ & - \\
\hline Northern fulmar & 0.54 & 55.0 & 56.5 & $4.38^{* *}$ & - & $1.00^{* *, 2}$ & $6.28^{* *}$ & $* *$ \\
\hline Murres & 0.50 & 52.5 & 4.1 & $3.67^{* *}$ & - & $6.21^{* *}$ & $8.64^{* *}$ & - \\
\hline Diving piscivores & 0.49 & 51.1 & 38.1 & $3.89^{* *}$ & - & $6.25^{* *}$ & $8.65^{* *}$ & - \\
\hline Non-central-place foragers & 0.38 & 40.4 & 37.6 & $3.38^{* *}$ & $5.35^{* *}$ & $4.64^{* *}$ & $3.59^{* *}$ & * \\
\hline Shearwaters & 0.37 & 49.0 & 35.2 & $3.41^{* *}$ & $5.30^{* *}$ & $4.38^{* *}$ & $3.27^{*}$ & * \\
\hline Surface piscivores & 0.34 & 36.3 & 60.4 & $2.18^{*}$ & - & $3.09^{* *}$ & $4.41^{* *}$ & - \\
\hline Kittiwakes & 0.34 & 36.5 & 55.1 & $1.88^{*}$ & - & $4.45^{* *}$ & $4.63^{* *}$ & * \\
\hline Diving planktivores & 0.15 & 17.6 & 4.5 & - & $1.00 *, 2$ & - & $7.92^{* *}$ & - \\
\hline Gulls & 0.07 & 8.2 & 2.7 & - & - & $2.84^{* *}$ & - & - \\
\hline
\end{tabular}


Fig. 4. Response curves from the best fitting generalized additive models (GAMs) for the effect of prey and spatial explanatory variables on the summer breeding season density of the 2 most abundant surface-feeding (northern fulmars, $\mathrm{R}^{2}=0.54$ ) and diving (murres, $\mathrm{R}^{2}=0.50$ ) seabirds (see Table 1). Explanatory variables included $(a, b)$ age-1 walleye pollock, $(c, d)$ latitude, and $(e, f)$ longitude. In each panel the solid line is the smooth function, dashed lines are $95 \%$ confidence intervals, and the distribution of points is indicated by tick marks on the $x$--axis
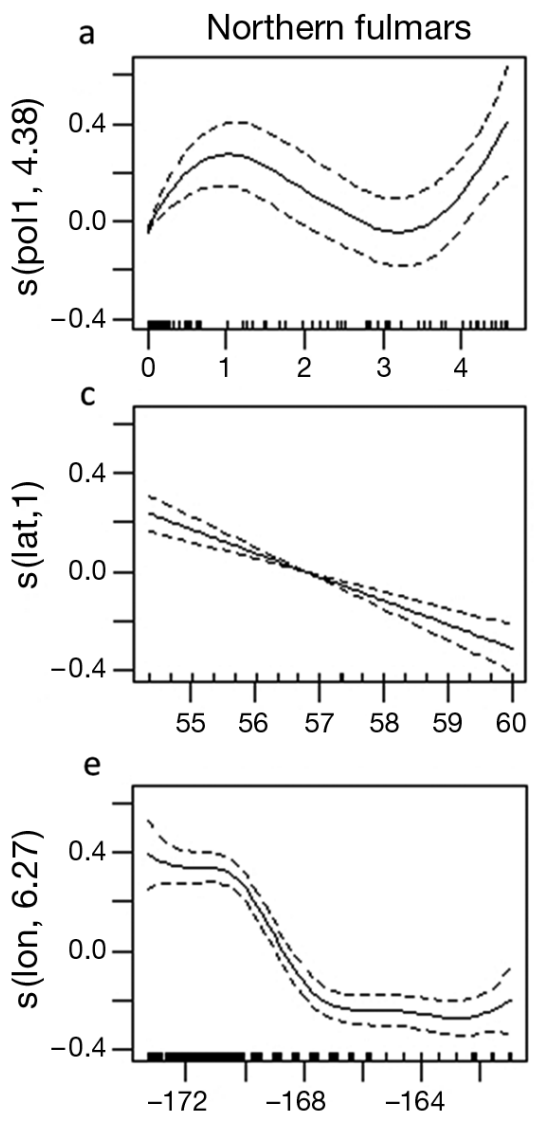
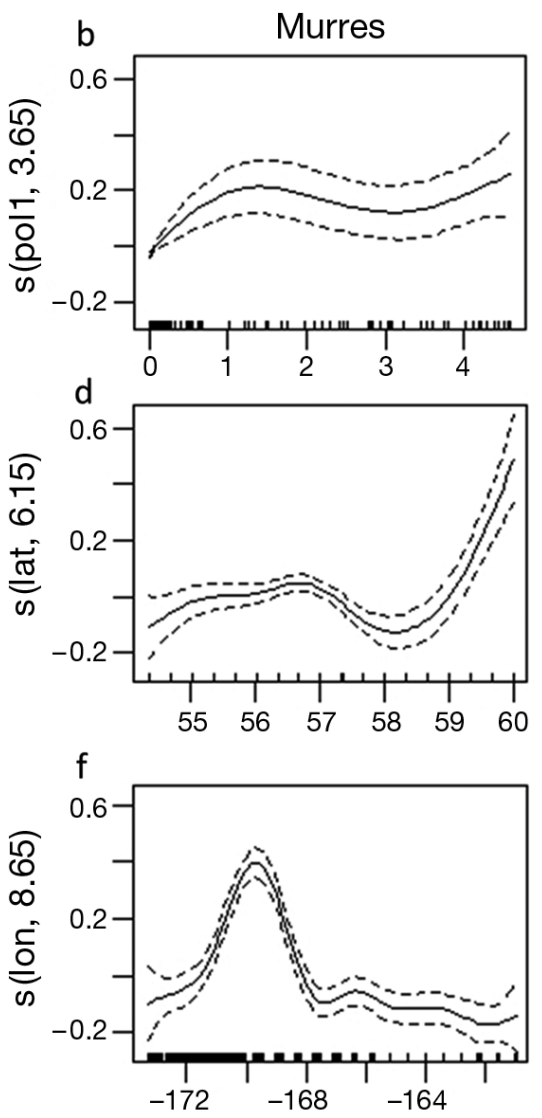

curve), other prey species (negative), and spatial variables of water depth, bottom temperature, and latitude (Table 6, Fig. 5). Murre density was best explained by all water column prey (positive) and depth of the mixed layer (negative asymptotic; Table 6, Fig. 5). Prey categories that were retained in models for 2 to 3 seabird species or groups included: all prey (murres, diving planktivores), age-0 Pacific cod (northern fulmars, shearwaters, surface piscivores), capelin (shearwaters, surface piscivores), and other fish species (northern fulmars, diving piscivores). The forage fish category was only included in very weak models $\left(\mathrm{R}^{2}=0.07-0.13\right)$ of surface planktivores and age- 0 pollock was not retained in any fall seabird-prey models.

\section{DISCUSSION}

The summer to fall transition in the SEBS resulted in an increase in avian species richness, abundance, and a greater dispersion of seabirds over the continental shelf. This pattern was remarkably consistent among all seabird categories considered and was to some extent contrary to our ini- tial hypothesis that seasonal spatial patterns would vary by taxa, foraging guilds, and behavior groups. Although seabirds in summer were more patchily distributed, they had more consistent associations with prey and spatial habitat variables compared to seabirds in the fall. This supported our hypothesis that seabird-prey and seabird-habitat associations would vary by season, taxa, guild, and behavior group. Static spatial features, however, such as water depth (fall only) and longitude (both seasons) were prominent explanatory variables in the final models, emphasizing that strong spatial gradients in habitats of the SEBS impact both predator and prey distribution, despite considerable differences in diets, foraging strategies, and life histories among species and interannual variation in prey abundance. Whereas we cannot directly compare the relative strength of seabird-prey associations between summer and fall due to sampling of different prey and metrics used, it is interesting to note the importance of static spatial variables in modeling seabird distribution, which is somewhat contrary to our initial hypothesis that dynamic variables of prey abundance and water column structure would be stronger predictors. 
Table 6. Results of generalized additive models (GAM) for bird abundance in fall vs. prey backscatter and spatial variables in the southeastern Bering Sea, 2008-2010. Models were evaluated separately using prey acoustically detected in the surface layer (Surf, $\mathrm{n}=148$ grid cells, $37 \times 37 \mathrm{~km}$ ) or for the water column (Wcol, $\mathrm{n}=107$ cells). The best model for each prey depth category is presented. Seabird groups as in Table 5, see Table 1 for species included in species groupings. Prey abundance and spatial variables include all fish, forage fishes (all fish excluding other species), age-0 pollock (Pol0), age-0 Pacific cod (Pcod0), capelin, other fish species (see Table 1), layer bottom, water depth, bottom water temperature, latitude, longitude, and year. All variables were quantitative, except year, which was modeled as a factor. GAM results include adjusted $\mathrm{R}^{2}$, percent deviance explained, $\triangle \mathrm{AIC}$, estimated degrees of freedom for significant smoothed variables, and their significance indicated as ${ }^{*} p<0.05$ or ${ }^{* *} p<0.001$. Superscripts indicate a ${ }^{1}$ positive and ${ }^{2}$ a negative linear relationship. $(-)$ indicates that the variable was included in the final model, but was not significant. $\triangle \mathrm{AIC}$ is the decrease in AIC between the final model and the next best of the 3 candidate models evaluated (Eqs. 2, $3 \& 4$ )

\begin{tabular}{|c|c|c|c|c|c|c|c|c|c|c|c|c|c|c|c|c|}
\hline $\begin{array}{c}\text { Species } \\
\text { group }\end{array}$ & $\begin{array}{l}\text { Prey } \\
\text { depth }\end{array}$ & $\mathrm{R}^{2}$ & $\%$ dev & $\Delta \mathrm{AIC}$ & $\begin{array}{l}\text { All } \\
\text { fish }\end{array}$ & $\begin{array}{c}\text { Forage } \\
\text { fish }\end{array}$ & Pol0 & Pcod0 & Capelin & $\begin{array}{l}\text { Other } \\
\text { fish }\end{array}$ & $\begin{array}{c}\text { Layer } \\
\text { bottom }\end{array}$ & $\begin{array}{l}\text { Water } \\
\text { depth }\end{array}$ & $\begin{array}{l}\text { Water } \\
\text { temp }\end{array}$ & Lat & Long & Year \\
\hline \multirow{2}{*}{$\begin{array}{l}\text { Northern } \\
\text { fulmar }\end{array}$} & Surf & 0.60 & 66.7 & 18.0 & & & - & $4.2^{*}$ & - & $4.4^{*}$ & $1.1^{*, 1}$ & $1.0^{*, 2}$ & $1.9^{*}$ & $1.0^{*, 2}$ & $7.6^{*}$ & - \\
\hline & Wcol & 0.66 & 75.6 & 7.1 & & & - & $7.8^{* *}$ & - & $2.6^{*}$ & - & $6.3^{*}$ & $4.0^{*}$ & $1.0^{*}, 2$ & - & - \\
\hline \multirow[t]{2}{*}{ Murres } & Surf & 0.42 & 54.4 & 12.0 & & & - & - & - & - & - & $7.8^{*}$ & - & - & - & - \\
\hline & Wcol & 0.44 & 53.5 & 4.9 & $1.0^{*}$ & & & & & & $2.9^{*}$ & - & - & - & - & * \\
\hline \multirow[t]{2}{*}{ Dive pisc } & Surf & 0.34 & 50.1 & 25 & & & - & - & - & - & - & $8.7^{*}$ & - & - & - & - \\
\hline & Wcol & 0.38 & 46.7 & 4.0 & & & - & - & - & $3.5^{*}$ & - & - & - & - & - & $* *$ \\
\hline \multirow[t]{2}{*}{ Shearwaters } & Surf & 0.22 & 31.1 & 22.5 & - & & & & & & $1.0 *, 2$ & - & - & $5.2^{*}$ & - & - \\
\hline & Wcol & 0.39 & 53.7 & 4.5 & & & - & $2.1^{*}$ & $1.0^{*}$ & - & $5.7^{* *}$ & - & - & - & - & - \\
\hline \multirow[t]{2}{*}{ Dive plank } & Surf & 0.36 & 46.3 & 5.7 & & & - & - & - & - & - & $5.2^{*}$ & - & - & - & * \\
\hline & Wcol & 0.28 & 33.8 & 4.1 & $1.0^{*, 2}$ & & & & & & $1.0^{*, 1}$ & - & $1.0^{* *, 2}$ & $1.0^{*, 2}$ & $1.0^{*, 2}$ & * \\
\hline \multirow[t]{2}{*}{ All seabirds } & Surf & 0.08 & 10.6 & 6.6 & - & - & - & - & - & - & - & - & - & - & $3.8^{*}$ & - \\
\hline & Wcol & 0.33 & 46.7 & 6.6 & & - & & & & & - & - & - & - & - & ${ }^{* *}$ \\
\hline \multirow[t]{2}{*}{ Surf pisc } & Surf & 0.24 & 34.0 & 10.9 & & & - & $7.9^{*}$ & $1.0^{*, 1}$ & - & - & - & - & - & - & - \\
\hline & Wcol & 0.31 & 45.8 & 5.0 & & - & & & & & - & - & - & - & $3.1^{*}$ & $*$ \\
\hline \multirow[t]{2}{*}{ Kittiwakes } & Surf & 0.22 & 28.5 & 24.3 & - & & & & & & - & - & - & - & $3.7^{*}$ & - \\
\hline & Wcol & 0.25 & 29.4 & 27.3 & - & & & & & & - & - & - & $1.0^{* *}$ & $2.8^{*}$ & * \\
\hline \multirow[t]{2}{*}{ Gulls } & Surf & 0.06 & 11.2 & 2.4 & & - & & & & & - & - & - & - & - & - \\
\hline & Wcol & 0.18 & 30.1 & 2.4 & - & & & & & & - & - & $2.1^{*}$ & - & - & * \\
\hline \multirow[t]{2}{*}{ Surf plank } & Surf & 0.13 & 21.1 & 5.5 & & $1.7^{*}$ & & & & & - & $7.6^{*}$ & - & - & - & - \\
\hline & Wcol & 0.07 & 18.5 & 2.6 & & $1.0^{*, 1}$ & & & & & - & - & - & - & - & - \\
\hline
\end{tabular}

\section{Temporal variability in seabird abundance}

Interannual variation in seabird abundance during our study period appeared to reflect changes in distribution over a broader region than our study area in response to prey. For example, northern fulmars and shearwaters were in higher abundance at sea during summer 2009 compared to 2008 and 2010 in our study area. Similarly, farther north in the Chukchi Sea, northern fulmars were more abundant in 2009 when warm Bering Sea water intruded early and stayed late into summer (Gall et al. 2013). In the SEBS, increased seabird abundance in 2009 mirrors the increase in summer age-1 pollock abundance from 2008 to 2009 (our data and Ressler et al. 2012, 2014).

Annual variability in seabird density at sea was greater in summer vs. fall. During the summer breeding season, in particular, there are many variables that can affect the number of birds at sea within varying radii around the colony, including the proportion of breeding birds that skip or fail breeding allowing them to spend more time and range more broadly at sea, thereby impacting annual densities observed during at sea surveys. For example, the proportion of northern fulmars attending colonies in Alaska can vary from 50 to $100 \%$ of maximum counts during consecutive years (Dragoo et al. 2015). Likewise, the breeding success of black-legged kittiwakes can vary from 0 to $>60 \%$ of breeding pairs successfully rearing young at a colony (Dragoo et al. 2015). In years of low reproductive success, such as 2009 for black-legged kittiwakes (Dragoo et al. 2015), fewer birds may attend the colony and therefore more birds are observed at sea during the summer breeding season, which is consistent with our results. In contrast, during fall surveys very few birds are still attending colonies so the proportion of the population that is at sea varies little among years. Also, increased species diversity and abundance of seabirds during fall is consistent with other high latitude regions (Ainley et al. 1994) as species from many different breeding areas, including fresh or brackish water breeding habitats, such as loons, grebes, and phalaropes, converge on food resources at sea in the post-breeding season. 

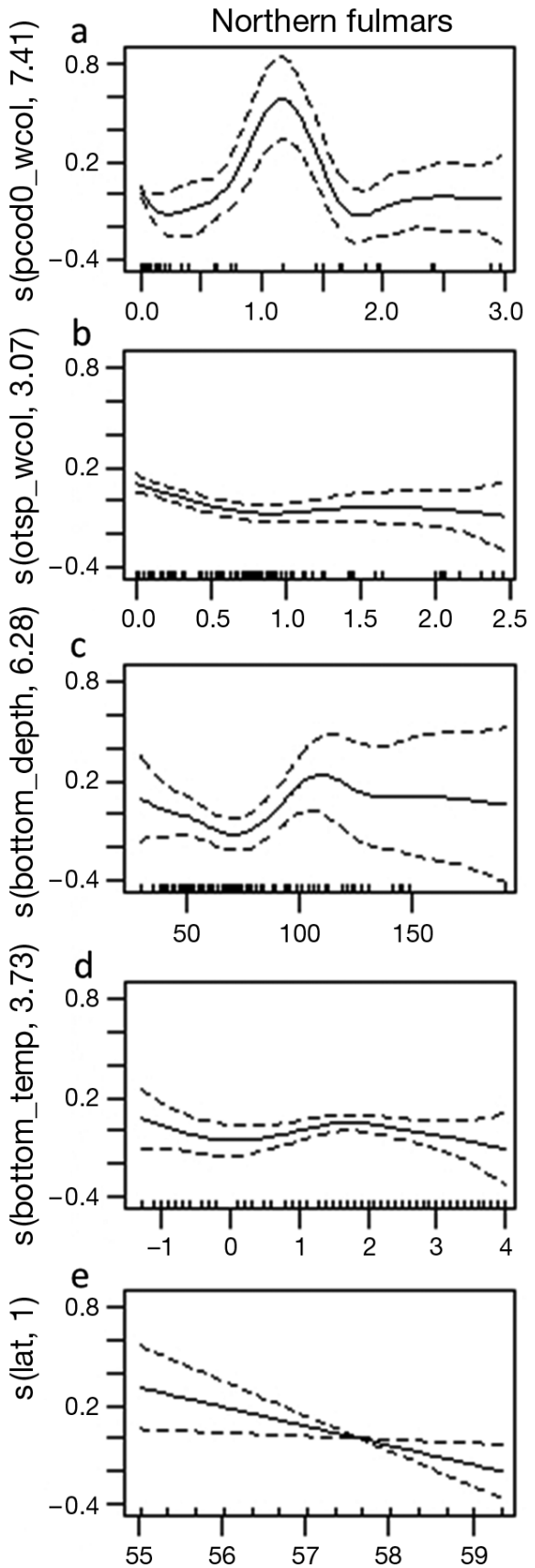

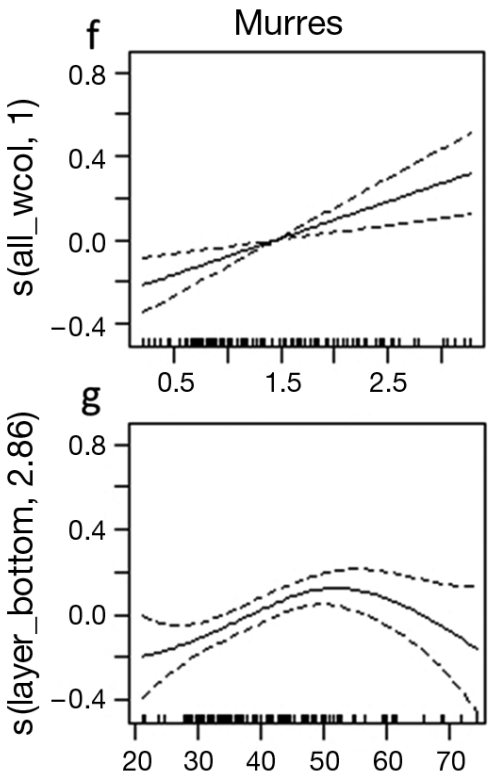

Fig. 5. Response curves from the best fitting GAMs for the effect of prey (water column) and spatial explanatory variables on the fall density of the 2 most abundant surfacefeeding (northern fulmars, $\mathrm{R}^{2}=$ 0.66) and diving (murres, $R^{2}=0.44$ ) seabirds (see Table 1). Explanatory variables included (a) age-0 Pacific cod, (b) other fish species, (c) bottom depth, (d) bottom temperature, and latitude for (e) northern fulmars and (f) all prey, and (g) layer bottom for murres. In each panel the solid line is the smooth function, dashed lines are 95\% confidence intervals, and the distribution of points is indicated by tick marks on the $x$-axis

ever; diving seabirds, such as thickbilled murre, show a stronger colony effect than surface-feeding black-legged kittiwakes (Sigler et al. 2012). The more colony-centric distribution of thick-billed murre was also evident in their isotopic signatures, which were found to have strong spatial patterns around the Pribilof Island colonies, compared to the dispersed isotopic signatures of black-legged kittiwakes at the same colonies (Jones et al. 2014). However, the central-place foraging effect during summer did not appear to limit some broad-scale seabird-prey associations in our study.

The importance of static spatial variables, especially water depth and longitude, on seabird distribution in the SEBS is consistent with previous studies showing the importance of spatial variables in models of prey distribution (e.g. euphausiids; Ressler et al. 2014) and seabird affinities for cross-shelf bathymetric domains of inner $(<50 \mathrm{~m}$ depth), middle (50 to $100 \mathrm{~m}$ ), outer (100 to $200 \mathrm{~m}$ ), and shelf-slope (200 to $3000 \mathrm{~m}$ ) (Schneider \& Hunt 1982, Hunt et al. 2014). These bathymetric domains are also differentiated hydrographically, particularly during summer, with a well-mixed water column on the inner shelf and stratified water over the middle to outer shelf and slope (Sigler et al. 2011). Varying bathymetric and hydrographic domains greatly affect seabird foraging and distribution in this region (Hunt et al. 1981, 2014

\section{Spatial variability in seabird abundance}

The more aggregated distribution of seabirds during the summer was largely, but not exclusively, driven by central-place foraging species, which are a major component of the seabird community during summer. An examination of 4 decades of at-sea surveys showed that for northern fulmars, colony effect was a key factor in modeling the distribution of this highly abundant species in the SEBS (Renner et al. 2013). Colony effect can vary among seabirds, how-
Kokubun et al. 2010). As with Hunt et al. (2014), who used a smaller region but much longer time series (37 yr), we found that diving piscivores and planktivores were more abundant over shallow inner and midshelf waters, whereas surface-feeding seabirds were in deeper, outer shelf-slope waters. We also found patterns between seabird foraging guilds and water mass characteristics similar to those observed in the Aleutian Islands (Jahncke et al. 2005, Ladd et al. 2005), despite very different marine habitats; the Aleutian Islands have a narrow continental shelf (10s 
of $\mathrm{km}$ ) with deep trenches or shallow shelves between islands, in contrast to the broad (100s of $\mathrm{km}$ ), relatively shallow shelf of the Bering Sea. For example, surface-feeding northern fulmars were primarily observed in the oceanic waters of the central Aleutians and diving shearwaters in coastal marine waters of the eastern Aleutian Islands (Jahncke et al. 2005). Moreover, diving seabirds in the Aleutian Islands occupied turbulent, well-mixed water masses near shallow water passes, whereas surface-feeding seabirds occurred near surface convergences over deep water passes (Ladd et al. 2005). Such consistent patterns of foraging associations across habitat spectrums suggest physical limitations to changes in prey distribution. However, water column stratification and prey type can alter seabird foraging behavior; Kokubun et al. (2010) found significant interannual variation in seabird foraging patterns in relation to water mass characteristics. In their study of individually tracked thick-billed murres, foraging behavior varied annually with the intensity of the thermocline and water temperature, likely through intermediate effects on the vertical distribution of prey.

The hydrography of the SEBS shelf varies seasonally, with much of the shelf becoming well mixed in fall and winter (Kinder \& Schumacher 1981, Stabeno et al. 2001, Kachel et al. 2002) which is consistent with our results that indicated all seabirds (including nonbreeding visitors such as shearwaters) were responding to large-scale changes in seasonal prey availability and not simply a release from central-place foraging constraints after the summer breeding season. The dispersal of seabirds across the SEBS shelf, however, appears to occur multi-directionally. Consistent with our findings, but using a much longer time series and a more detailed seasonal analysis, Hunt et al. (2014) found that some nearshore species in the SEBS moved further inshore from summer to fall; diving seabirds shifted their relative distribution from inshore during summer to offshore in fall, while the relative distribution of surface-feeding species showed an opposite trend and shifted from offshore to inshore.

\section{Seabird-prey associations}

In summer, seabirds, including all foraging groups, except diving planktivores and gulls, were more closely associated with patchily distributed walleye pollock rather than the more uniformly dispersed euphausiids (at the coarse scale of our analysis). Our results included a subset of data used in Sigler et al. (2012) and are consistent with their findings despite using different methods and their larger study area in the Bering Sea. In contrast, during fall the more dispersed distribution of seabirds over the middle SEBS shelf is consistent with observed distributions of several forage fish species throughout this region (ParkerStetter et al. 2013). Capelin, for example, which historically was a larger component of seabird diets in the Bering Sea compared to recent decades (Sinclair et al. 2008, Renner et al. 2012), was only important in our models for shearwaters, which are omnivorous (Hunt et al. 2002a, Baduini et al. 2006), and surface piscivores (in fall only since we did not measure capelin abundance in summer). Capelin distribution exhibits high interannual variability, apparently mediated by ocean temperature (Ciannelli \& Bailey 2005). During 2009 in particular, high water column densities of capelin were found in the middle and outer shelf regions, i.e. between the 50 to $100 \mathrm{~m}$ and 100 to $200 \mathrm{~m}$ isobaths, respectively (Fig. 1; ParkerStetter et al. 2013), which is consistent with the stronger shearwater-capelin association that we detected that year (Fig. S4 in the Supplement). In fall, free from the constraint of central-place foraging and the energy demands of chick-rearing, seabirds are presumably able to be less selective and more omnivorous in their prey consumption. Our data and analyses of seabird prey in summer or fall, however, did not include some species such as squids (Gonatidae) and mesopelagic fishes (Myctophidae) that are known to be important prey for some seabird species or colonies in the Bering Sea (Sinclair et al. 2008, Renner et al. 2012).

Other factors that affect the coherence of predators and prey include prey abundance (Skov et al. 2000, Davoren \& Montevecchi 2003, Vlietstra 2005) and the spatial resolution of predator-prey integration (Schneider \& Piatt 1986, Mehlum et al. 1999, Fauchald et al. 2000). Seabirds and prey can be more tightly coupled when prey and seabird abundance is relatively high (Mehlum et al. 1999, Fauchald et al. 2000), although exceptions do exist, i.e. instances where seabird-prey coupling is stronger when prey abundance is low, especially at small temporal scales (Vlietstra 2005, Ainley et al. 2009). Metrics of prey abundance alone, however, are rarely good predictors of seabird abundance unless the scale of the foraging behavior of a particular predator matches the distribution patterns of the prey (Russell et al. 1992, Davoren et al. 2002, Benoit-Bird et al. 2011, Santora \& Reiss 2011). Spatial scales at which seabirds track prey have been shown to range from coarse to fine. For example, Fauchald et al. (2000) and Fauchald \& Erikstad (2002) identified an overlap between murres and capelin in the Barents Sea at large spatial scales 
(50 to $300 \mathrm{~km})$, but no overlap at small scales $(3 \mathrm{~km})$. Other studies have found that associations exist at 3 to $9 \mathrm{~km}$ spatial scales between common murres and capelin in the northeast Atlantic (Davoren et al. 2002) and between thick-billed murres and vertebrate (polar cod Boreogadus saida) and invertebrate (pelagic amphipods, euphausiids) prey in the Barents Sea (Mehlum et al. 1999), while associations at finer $(<1 \mathrm{~km})$ resolution were weak. Benoit-Bird et al. (2011) demonstrated in the SEBS that fine-scale analyses examining predator-prey associations may perform best using multi-species prey aggregations. Furthermore, the distribution of prey patches was important and euphausiid patches targeted by diving murres were generally of higher density and located closer to the surface. Similar patterns held true for surface-feeding and diving species where metrics of prey depth and patch density within larger prey aggregations were stronger predictors of predator densities or foraging activities than more coarse measures of prey biomass and abundance in vastly different ecosystems of the Bering Sea and Humboldt Current (Benoit-Bird et al. 2013, Boyd et al. 2015). Our rather coarse $37 \times 37 \mathrm{~km}$ spatial analysis identified greater association between predators and prey in fall using water column prey density rather than surface density (above the mixed layer depth), regardless of vertical feeding depth of seabirds, and only $40 \%$ of the final models included mixed layer depth, which is contrary to our initial hypothesis that water column structure would be one of the more important variables affecting seabird density. Our result can partly be explained by variability in the vertical distribution of prey, where for some species or in some years the density may be similar between surface and deep waters, whereas in other years prey become more abundant in surface vs. deep waters and vice versa (our results and Parker-Stetter et al. 2013). More detailed metrics of prey vertical distribution, patch aggregation, and patch density would likely have improved our models of seabird-prey relationships, especially at finer spatial resolutions.

Long-term climate variability has been linked to shifts in prey distribution in the Bering Sea (Mueter \& Litzow 2008, Mueter et al. 2011, Simpson et al. 2011). Likewise, long-term, northward shifts in the distribution of seabirds have also been observed in the Bering Sea (Renner et al. 2013, Kuletz et al. 2014), as well as the occurrence of new species farther north into the Chukchi Sea (Day et al. 2013). Additionally, long-term studies of seabird colonies in the Bering Sea indicate that food web changes may be more pronounced for near-surface foraging guilds compared to those forag- ing at depth (Byrd et al. 2008). Our results identify annual and seasonal variability in abundance and seabird-prey and spatial-temporal habitat associations over a relatively short 3 yr period during a cold regime in the Bering Sea (Stabeno et al. 2012b). These results will help to provide insight into mechanisms affecting mesoscale seabird-prey relationships and enhance understanding of how these abundant mid-upper trophic level consumers will respond to climate variability in the Bering Sea. Further studies that include quantifying the same species of prey in summer and fall, an aspect which was lacking in our study, would be valuable to directly assess factors affecting temporal changes in seabird-prey associations and prey habitat requirements, especially during the littlestudied fall post-breeding season.

Acknowledgements.We thank the many scientists who collected the seabird and fisheries data and the captains and crews of the research vessels used in these efforts. This work was supported in part by the Alaska Fisheries Science Center, National Marine Fisheries Service, NOAA, the US Fish and Wildlife Service, and the North Pacific Research Board and National Science Foundation as part of the BESTBSIERP Bering Sea Project. Drafts of this manuscript benefited from comments by J. Zamon and 2 anonymous reviewers. The findings and conclusions in this paper are those of the authors and do not necessarily represent the views of the National Marine Fisheries Service, NOAA, or the US Fish and Wildlife Service. Reference to trade names does not imply endorsement by the National Marine Fisheries Service, NOAA. This paper is BEST-BSIERP Bering Sea Project publication \#178 and NPRB publication number \#581.

\section{LITERATURE CITED}

Ainley DG, Ribic CA, Fraser WR (1994) Ecological structure among migrant and resident seabirds of the ScotiaWeddell Confluence region. J Anim Ecol 63:347-364

Ainley DG, Dugger KD, Ford RG, Pierce SD and others (2009) Association of predators and prey at frontal features in the California Current: competition, facilitation, and co-occurrence. Mar Ecol Prog Ser 389:271-294

Baduini CL, Hunt GL Jr, Pinchuk AI, Coyle KO (2006) Patterns in diet reveal foraging site fidelity of short-tailed shearwaters in the southeastern Bering Sea. Mar Ecol Prog Ser 320:279-292

> Benoit-Bird KJ, Kuletz K, Heppell S, Jones N, Hoover B (2011) Active acoustic examination of the diving behavior of murres foraging on patchy prey. Mar Ecol Prog Ser 443:217-235

Benoit-Bird KJ, Battaile BC, Heppell SA, Hoover B and others (2013) Prey patch patterns predict habitat use by top marine predators with diverse foraging strategies. PLoS ONE 8:e53348

> Boyd C, Castillo R, Hunt GL, Punt AE, VanBlaricom GR, Weimerskirch H, Bertrand S (2015) Predictive modelling of habitat selection by marine predators with respect to the abundance and depth distribution of pelagic prey. J Anim Ecol 84:1575-1588 
Brodeur RD, Wilson MT, Walters GE, Melnikov IV (1999) Forage fishes in the Bering Sea: distribution, species associations, and biomass trends. In: Loughlin T, Ohtani K (eds) Dynamics of the Bering Sea. Alaska Sea Grant, Fairbanks, AK, p 509-536

Brodeur RD, Wilson MT, Ciannelli L, Doyle M, Napp JM (2002) Interannual and regional variability in distribution and ecology of juvenile pollock and their prey in frontal structures of the Bering Sea. Deep-Sea Res II 49: 6051-6067

Burke CM, Montevecchi WA (2009) The foraging decisions of a central place foraging seabird in response to fluctuations in local prey conditions. J Zool (Lond) 278:354-361

Byrd GV, Sydeman WJ, Renner HM, Minobe S (2008) Responses of piscivorous seabirds at the Pribilof Islands to ocean climate. Deep-Sea Res II 55:1856-1867

> Ciannelli L, Bailey KM (2005) Landscape dynamics and resulting species interactions: the cod-capelin system in the southeastern Bering Sea. Mar Ecol Prog Ser 291: $227-236$

Coyle KO, Eisner LB, Mueter FJ, Pinchuk AI and others (2011) Climate change in the southeastern Bering Sea: impacts on pollock stocks and implications for the oscillating control hypothesis. Fish Oceanogr 20:139-156

> Davoren GK, Montevecchi WA (2003) Search strategies of a pursuit-diving marine bird and the persistence of prey patches. Ecol Monogr 73:463-481

> Davoren GK, Montevecchi WA, Anderson JT (2002) Scaledependent associations of predators and prey: constraints imposed by flightlessness of common murres. Mar Ecol Prog Ser 245:259-272

Day RH, Gall AE, Morgan TC, Rose JR and others (2013) Seabirds new to the Chukchi and Beaufort seas, Alaska: response to a changing climate? West Birds 44:174-182

> De Robertis A, McKelvey DR, Ressler PH (2010) Development and application of an empirical multifrequency method for backscatter classification. Can J Fish Aquat Sci 67:1459-1474

Dragoo DE, Renner HM, Irons DB (2015) Breeding status and population trends of seabirds in Alaska, 2014. Report AMNWR 2015/03, US Fish and Wildlife Service, Homer, AK

Farley EVJ, Murphy J, Moss J, Feldmann A, Eisner L (2009) Marine ecology of western Alaska juvenile salmon. In: Krueger CC, Zimmerman CE (eds) Pacific salmon: ecology and management of western Alaska's populations. American Fisheries Society, Bethesda, MD, p 307-329

Fauchald P, Erikstad KE (2002) Scale-dependent predatorprey interactions: the aggregative response of seabirds to prey under variable prey abundance and patchiness. Mar Ecol Prog Ser 231:279-291

Fauchald P, Erikstad KE, Skarsfjord H (2000) Scaledependent predator-prey interactions: the hierarchical spatial distribution of seabirds and prey. Ecology 81: 773-783

> Gall AE, Day RH, Weingartner TJ (2013) Structure and variability of the marine-bird community in the northeastern Chukchi Sea. Cont Shelf Res 67:96-115

> Harding A, Paredes R, Suryan R, Roby D and others (2013) Does location really matter? An inter-colony comparison of seabirds breeding at varying distances from productive oceanographic features in the Bering Sea. Deep-Sea Res II 94:178-191

> Harvey HR, Sigler MF (2013) An introduction to the Bering Sea Project: Volume II. Deep-Sea Res II 94:2-6
Hollowed AB, Barbeaux SJ, Cokelet ED, Farley E and others (2012) Effects of climate variations on pelagic ocean habitats and their role in structuring forage fish distributions in the Bering Sea. Deep-Sea Res II 65-70:230-250

Honkalehto T, McCarthy A, Ressler P, Stienessen S, Jones D (2010) Results of the acoustic-trawl survey of walleye pollock (Theragra chalcogramma) on the US and Russian Bering Sea shelf in June-August 2009 (DY0909). AFSC Processed Rep 2010-03. Alaska Fisheries Science Center, National Marine Fisheries Service, NOAA, Seattle, WA

Hunt GL Jr, Gould P, Forsell DJ, Peterson H (1981) Pelagic distribution of marine birds in the eastern Bering Sea. In: Hood DW, Calder JA (eds) The eastern Bering Sea shelf: oceanography and resources. NOAA, Washington, DC, p 689-718

Hunt GL Jr, Baduini C, Jahncke J (2002a) Diets of shorttailed shearwaters in the southeastern Bering Sea. DeepSea Res II 49:6147-6156

Hunt GL Jr, Stabeno P, Walters G, Sinclair E, Brodeur RD, Napp JM, Bond NA (2002b) Climate change and control of the southeastern Bering Sea pelagic ecosystem. DeepSea Res II 49:5821-5853

> Hunt GL Jr, Coyle KO, Eisner LB, Farley EV and others (2011) Climate impacts on eastern Bering Sea foodwebs: a synthesis of new data and an assessment of the Oscillating Control Hypothesis. ICES J Mar Sci 68:1230-1243

> Hunt GL Jr, Renner M, Kuletz K (2014) Seasonal variation in the cross-shelf distribution of seabirds in the southeastern Bering Sea. Deep-Sea Res II 109:266-281

> Jahncke J, Coyle KO, Hunt GL Jr (2005) Seabird distribution, abundance and diets in the eastern and central Aleutian Islands. Fish Oceanogr 14:160-177

> Jahncke J, Vlietstra LS, Decker MB, Hunt GL Jr (2008) Marine bird abundance around the Pribilof Islands: a multiyear comparison. Deep-Sea Res II 55:1809-1826

Jones NM, Hoover BA, Heppell SA, Kuletz KJ (2014) A cross-shelf gradient in $\delta^{15} \mathrm{~N}$ stable isotope values of krill and pollock indicates seabird foraging patterns in the Bering Sea. Deep-Sea Res II 109:241-250

Kachel NB, Hunt GL Jr, Salo SA, Schumacher JD, Stabeno PJ, Whitledge TE (2002) Characteristics and variability of the inner front of the southeastern Bering Sea. Deep-Sea Res II 49:5889-5909

Kinder TH, Schumacher JD (1981) Hydrographic structure over the continental shelf of the southeastern Bering Sea. In: Hood DW, Calder JA (eds) The eastern Bering Sea shelf: oceanography and resources, Vol 1. US Government Printing Office, Washington, DC, p 31-52

Kitaysky AS, Golubova EG (2000) Climate change causes contrasting trends in reproductive performance of planktivorous and piscivorous alcids. J Anim Ecol 69:248-262

Kokubun N, Takahashi A, Ito M, Matsumoto K, Kitaysky AS, Watanuki Y (2010) Annual variation in the foraging behaviour of thick-billed murres in relation to upper-ocean thermal structure around St. George Island, Bering Sea. Aquat Biol 8:289-298

Kuletz KJ, Renner M, Labunski EA, Hunt GL Jr (2014) Changes in the distribution and abundance of albatrosses in the eastern Bering Sea: 1975-2010. Deep-Sea Res II 109:282-292

> Ladd C, Jahncke J, Hunt GL, Coyle KO, Stabeno PJ (2005) Hydrographic features and seabird foraging in Aleutian Passes. Fish Oceanogr 14:178-195

Markones N, Dierschke V, Garthe S (2010) Seasonal differences in at-sea activity of seabirds underline high ener- 
getic demands during the breeding period. J Ornithol 151:329-336

Mason JW, McChesney GJ, McIver WR, Carter HR and others (2007) At-sea distribution and abundance of seabirds off southern California; a 20-year comparison. Stud Avian Biol 33:1-95

Mehlum F, Hunt GLJ, Klusek Z, Decker MB (1999) Scaledependent correlations between the abundance of Brunnich's guillemots and their prey. J Anim Ecol 68:60-72

> Mueter FJ, Litzow MA (2008) Sea ice retreat alters the biogeography of the Bering Sea continental shelf. Ecol Appl 18:309-320

> Mueter FJ, Bond NA, Ianelli JN, Hollowed AB (2011) Expected declines in recruitment of walleye pollock (Theragra chalcogramma) in the eastern Bering Sea under future climate change. ICES J Mar Sci 68:1284-1296

> Paredes R, Harding AMA, Irons DB, Roby DD and others (2012) Proximity to multiple foraging habitats enhances seabirds' resilience to local food shortages. Mar Ecol Prog Ser 471:253-269

Parker-Stetter SL, Horne JK, Farley EV, Barbee DH, Andrews Iii AG, Eisner LB, Nomura JM (2013) Summer distributions of forage fish in the eastern Bering Sea. Deep-Sea Res II 94:211-230

Parrish JK, Bond N, Nevins H, Mantua N, Loeffel R, Peterson WT, Harvey JT (2007) Beached birds and physical forcing in the California Current System. Mar Ecol Prog Ser 352:275-288

Piatt JF, Harding AMA, Shultz M, Speckman SG, van Pelt TI, Drew GS, Kettle AB (2007) Seabirds as indicators of marine food supplies: Cairns revisited. Mar Ecol Prog Ser 352:221-234

R Core Team (2013) R: a language and environment for statistical computing. R Foundation for Statistical Computing, Vienna

> Renner M, Hunt GL Jr, Piatt JF, Byrd GV (2008) Seasonal and distributional patterns of seabirds along the Aleutian Archipelago. Mar Ecol Prog Ser 357:301-311

Renner HM, Mueter F, Drummond BA, Warzybok JA, Sinclair EH (2012) Patterns of change in diets of two piscivorous seabird species during 35 years in the Pribilof Islands. Deep-Sea Res II 65-70:273-291

Renner M, Parrish JK, Piatt JF, Kuletz KJ, Edwards AE, Hunt GL Jr (2013) Modeled distribution and abundance of a pelagic seabird reveal trends in relation to fisheries. Mar Ecol Prog Ser 484:259-277

Ressler PH, De Robertis A, Warren JD, Smith JN, Kotwicki S (2012) Developing an acoustic survey of euphausiids to understand trophic interactions in the Bering Sea ecosystem. Deep-Sea Res II 65-70:184-195

> Ressler PH, De Robertis A, Kotwicki S (2014) The spatial distribution of euphausiids and walleye pollock in the eastern Bering Sea does not imply top-down control by predation. Mar Ecol Prog Ser 503:111-122

Russell RW, George L, Hunt J, Coyle KO, Cooney RT (1992) Foraging in a fractal environment: spatial patterns in a marine predator-prey system. Landscape Ecol 7:195-209

Santora JA (2014) Environmental determinants of top predator distribution within the dynamic winter pack ice zone of the northern Antarctic Peninsula. Polar Biol 37: 1083-1097

Santora JA, Reiss CS (2011) Geospatial variability of krill and top predators within an Antarctic submarine canyon system. Mar Biol 158:2527-2540

Schneider D, Hunt GL (1982) Carbon flux to seabirds in

Editorial responsibility: Jana Davis,

Annapolis, Maryland, USA waters with different mixing regimes in the southeastern Bering Sea. Mar Biol 67:337-344

Schneider DC, Piatt JF (1986) Scale-dependent correlation of seabirds with schooling fish in a coastal ecosystem. Mar Ecol Prog Ser 32:237-246

Schneider DC, Hunt GL Jr, Harrison NM (1986) Mass and energy transfer to seabirds in the southeastern Bering Sea. Cont Shelf Res 5:241-257

Sigler MF, Renner M, Danielson SL, Eisner LB and others (2011) Fluxes, fins, and feathers relationships among the Bering, Chukchi, and Beaufort Seas in a time of climate change. Oceanography (Wash DC) 24:250-265

Sigler MF, Kuletz KJ, Ressler PH, Friday NA, Wilson CD, Zerbini AN (2012) Marine predators and persistent prey in the southeast Bering Sea. Deep-Sea Res II 65-70: 292-303

Simpson SD, Jennings S, Johnson MP, Blanchard JL, Schön PJ, Sims DW, Genner MJ (2011) Continental shelf-wide response of a fish assemblage to rapid warming of the sea. Curr Biol 21:1565-1570

Sinclair EH, Vlietstra LS, Johnson DS, Zeppelin TK and others (2008) Patterns in prey use among fur seals and seabirds in the Pribilof Islands. Deep-Sea Res II 55:1897-1918

Skov H, Durinck J, Andell P (2000) Associations between wintering avian predators and schooling fish in the Skagerrak-Kattegat suggest reliance on predictable aggregations of herring Clupea harengus. J Avian Biol 31:135-143

Springer AM, Roseneau DG, Lloyd DS, McRoy CP, Murphy EC (1986) Seabird responses to fluctuating prey availability in the eastern Bering Sea. Mar Ecol Prog Ser 32: $1-12$

Stabeno PJ, Bond NA, Kachel NB, Salo SA, Schumacher JD (2001) On the temporal variability of the physical environment over the south-eastern Bering Sea. Fish Oceanogr 10:81-98

Stabeno PJ, Farley EV Jr, Kachel NB, Moore S and others (2012a) A comparison of the physics of the northern and southern shelves of the eastern Bering Sea and some implications for the ecosystem. Deep-Sea Res II 65-70: $14-30$

Stabeno PJ, Kachel NB, Moore SE, Napp JM, Sigler M, Yamaguchi A, Zerbini AN (2012b) Comparison of warm and cold years on the southeastern Bering Sea shelf and some implications for the ecosystem. Deep-Sea Res II 65-70:31-45

Tasker ML, Jones PH, Dixon T, Blake BF (1984) Counting seabirds at sea from ships: a review of methods employed and a suggestion for a standardized approach. Auk 101:567-577

Traynor JJ (1996) Target-strength measurements of walleye pollock (Theragra chalcogramma) and Pacific whiting (Merluccius productus). ICES J Mar Sci 53:253-258

USFWS (US Fish and Wildlife Service) (2009) Alaska seabird conservation plan. US Fish and Wildlife Service, Migratory Bird Management, Anchorage, AK

Vlietstra LS (2005) Spatial associations between seabirds and prey: effects of large-scale prey abundance on small-scale seabird distribution. Mar Ecol Prog Ser 291: 275-287

> Wood SN (2004) Stable and efficient multiple smoothing parameter estimation for generalized additive models. J Am Stat Assoc 99:673-686

Wood SN (2006) Generalized Additive Models: an introduction with R. Chapman \& Hall/CRC, Boca Raton, FL 